\title{
ANALISIS YURIDIS KONSEP OMNIBUS LAW DALAM HARMONISASI PERATURAN PERUNDANG- UNDANGAN DI INDONESIA
}

\author{
Nyoman Nidia Sari Hayati, Sri Warjiyati, Muwahid
}

\author{
Universitas Islam Negeri Sunan Ampel Surabaya
}

Jl. A. Yani 117, Surabaya, 60237

nnsarihayati@gmail.com,warjiyatisri@gmail.com,muwahidizza@gmail.com

\begin{abstract}
Indonesia as a country that adopts a civil law system has a lot of laws and regulations from the central to the regional level. The impact is a lot of overlapping regulations both vertically and horizontally. To arrange overlapping laws and regulations, harmonization is needed. The concept of the omnibus law has been successfully applied in several countries which mostly adhere to the common law system, but Indonesia which adheres to the civil law legal system is still new to this term. Thus the problem discussed in this study is how the concept of the omnibus law in building harmonization of legislation and what obstacles are experienced when this concept is applied in Indonesia.This research is a normative legal research using a statute approach, a comparative approach, and a conceptual approach. Then an analysis of all materials was carried out with a descriptive method. The results of this study indicate that the harmonization of legislation is very important for the development of law and for the creation of legal certainty in Indonesia. However, to make a law with the concept of the omnibus law requires in-depth study and involving many parties so that the transparency of its formation does not cause problems and harm the public.
\end{abstract}

Keywords: 0 mnibus Law, Harmonization of Laws and Regulations.

\begin{abstract}
Abstrak, Indonesia sebagai negara yang menganut sistem hukum civil law memiliki banyak sekali peraturan perundang-undangan mulai pusat sampai daerah.Dampaknya banyak terjadi tumpang tindih peraturan perundang-undangan baik secara vertikal maupun horizontal.Untuk menata peraturan perundang-undangan yang tumpang tindih diperlukan adanya harmonisasi.Konsep omnibus law telah berhasil diterapkan di beberapa negara yang kebanyakan menganut sistem common law, namun Indonesia yang menganut sistem hukum civil law masih baru mengenal istilah ini. Dengan demikian permasalahan yang dibahas dalam penelitian ini adalah bagaimna konsep omnibus law dalam membangun harmonisasi perundangan dan apa saja hambatan yang dialami apabila konsep ini diterapkan di Indonesia. Penelitian ini merupakan penelitian hukum normatif dengan menggunakan pendekatan perundang-undangan (statute approach), pendekatan perbandingan (comparative approach), dan pendekatan konseptual (conceptual approach).Kemudian dilakukan analisis terhadap semua bahan dengan metode deskriptif.Hasil dari penilitian ini menunjukkan bahwa harmonisasi perundang-undangan sangat penting dilakukan untuk pembangunan hukum dan demi terciptanya kepastian hukum di Indonesia. Namun untuk membuat Undang-Undang dengan konsep omnibus law memerlukan kajian mendalam dan melibatkan banyak pihak demi transparansi pembentukannya dupaya tidak menimbulkan permasalahan- permasalahan dan merugikan publik.
\end{abstract}

Katakuni: Omnibus Law, Harmonisasi Peraturan Perundang-undangan. 
Volume 16, Nomor 1, Januari - Juni 2021

\section{Pendahuluan}

Dalam negara hukum (rechstaat) yang bertumpu pada sistem Eropa Kontinental atau disebut juga dengan istilah Civil Law, ${ }^{1}$ peraturan perundang-undangan menjadi elemen penting dalam penyelenggaraan negara. Dalam perkembangannya, negara-negara yang menganut sistem hukum civil law di era kontemporer mulai menerapkan pentingnya yurisprudensi sebagai salah satu sumber hukum dalam sistem hukumnya, begitupun dengan negara-negara yang menganut sistem hukum common law yang mulai memberikan tempat yang seimbang untuk perundang-undangan. ${ }^{2}$ Batasan antar kedua sistem tersebut sudah sangat longgar dalam perbandingan hukum tata negara. ${ }^{3}$

Indonesia yang menganut sistem civil law sebagaimana negara-negara Eropa Kontinental pun salah satu sumber hukumnya adalah yurisprudensi, namun tetap peraturan perundang-undangan lah yang diutamakan, sesuai dengan tingkatan peraturan perundang-undangan yang berlaku.

Tingkatan peraturan perundang-undangan ini biasanya juga disebut dengan istilah hierarki diamana perundang-undangan yang ada di negara kita berjenjang atau bertingkat mulai yang paling dasar sebagai yang kedudukan tertinggi sampai pada yang dibawahnya. Teori jenjang norma ini dikemukakan oleh Hans Kelsen dan muridnya Hans Nawiasky.

Hierarki atau tingkatan perundang-undangan di Indonesia sampai saat ini sudah beberapa kali dirubah, yang terbaru adalah Undang-Undang No. 12 Tahun 2011 tentang Pembentukan Peraturan Perundang-undangan yang telah diperbarui dengan UndangUndang No. 15 Tahun 2019. Hierarki perundang-undangan ini diatur dalam Pasal 7 dan Pasal 8, yaitu: ${ }^{4}$

1. Undang-Undang Dasar Negara Republik Indonesia 1945 (UUD NRI 1945);

2. Ketetapa Majelis Permusyawaratan Rakyat (TAP MPR);

3. Undang-Undang (UU) / Peraturan Pemerintah Pengganti Undang-Undang (Perppu);

4. Peraturan Pemerintah (PP);

5. Peraturan Presiden (Perpres);

6. Peraturan Daerah Provinsi;

7. Peraturan Daerah Kabupaten/Kota.

\footnotetext{
${ }^{1}$ Ni’matul Huda, Hukum Tata Negara,(Jakarta: Rajawali Press,2014), hlm. 82.

${ }^{2}$ Mirza Satria Buana, "Menakar Konsep Omnibus Law dan Consolidation Law untuk Harmonisasi Peraturan Prundang-Undangan Indonesia: Pendekatan Perbandingan Hukum Tata Negara", Prosiding Konferensi Nasional Hukum Tata Negara (KNHTN) Ke-4: Penataan Regulasi di Indonesia, ed., Ghautama Budi Arundati, dkk, (Jember: UPT Penerbitan Universitas Jember, 2017), hlm. 303

${ }^{3}$ Adriaan Bedner, "Indonesia Legal Shcolarship and Jurisprudence as an Obstacle from Transplanting Legal Institutio ns", Hogue Journal of the Rule of Law 5, 2013. hlm. 235-273.

${ }^{4}$ Undang-Undang No. 15 Tahun 2019 tentang Perubahan atas Undang-Undang No. 12 Tahun 2011 tentang Pembentukan Peraturan Perundang-Undangan.
} 
Volume 16, Nomor 1, Januari - Juni 2021

Jenis perundang-undangan lainnya meliputi keputusan yang dikeluarkan oleh Majelis Permusyawartan Rakyat (MPR), Dewan Perwakilan Rakyat (DPR), Dewan Perwakilan Daerah (DPD), Mahkamah Agung (MA), Mahkamah Konstitusi (MK), Badan Pemeriksa Keuangan (BPK), Komisi Yudisial (KY), Bank Indonesia (BI), Menteri, badan, lembaga, atau komisi yang setingkat yang dibentuk dengan Undang-Undang atau Pemerintah atas perintah Undang-Undang, Dewan Perwakilan Daerah Provinsi, Gubernur, Dewan Perwakilan Daerah Kabupaten/Kota, Bupati/Walikota, Kepala Desa atau yang setingkat.

Banyaknya peraturan perundang-undangan di negara kita seperti yang telah disebutkan dalam Pasal 7 dan 8 dalam Undang-Undang tentang Pembentukan Perundangundangan ini seringkali mengakibatkankan adanya tumpang tindih peraturan yang menyebabkan obesitas peraturan perundang-undangan. Sering terjadi tidak sinkronnya peraturan antara pusat dan daerah yang dapat menyebabkan tidak adanya kepastian hukum dalam berbagai hal.

Misalnya dalam hal investasi, sering terjadi kesulitan investasi disebabkan karena sulitnya perizinan yang disebabkan oleh berbagai peraturan yang tumpang tindih dan sinkron antar pemerintah pusat dan daerah.Dalam praktek investasi di Indonesia ada beberapa regulasi yang berkaitan tentang pertanahan dan lingkungan. Dalam Pasal 35 Undang-Undang No. 5 Tahun 1960 tentang Peraturan Dasar Pokok-Pokok Agraria dinyatakan bahwa Hak Guna Bangunan (HGB) diberikan jangka waktu 30 tahun kemudian dapat diperpanjang selama 20 tahun. ${ }^{5}$ Berbeda dengan Hak Guna bangunan dalam Undang-Undang No. 25 Tahun 2007 tentang Penanaman Modal yang diberikan jangka waktu selama 80 tahun dengan memberikan dan diperpanjang di muka sekaligus dan dapat diperpanjang selama 30 tahun. ${ }^{6}$ Peraturan ini telah di judicial review ke Mahkamah Konstitusi yang menghasilkan putusan No. 21-22/PUU-V/2007.Dalam permasalahan tidak harmonisnya peraturan perundang-undangan dapat dilakukan judicial review baik di Mahkamah Agung maupun di Mahkamah Konstitusi.

Dengan demikian diperlukan pengharmonisan berbagai peraturan perundangundangan yang ada di Indonesia. Disharmonisasi peraturan perundang-undangan ini disebabkan oleh beberapa hal, diantaranya: ${ }^{7}$

1. Pembentukan peraturan yang dilakukan oleh lembaga yang berbeda-beda dalam waktu yang berbeda pula;

2. Dalam proses pembentukannya, pejabat yang berwenang membentuk perundangundangan berganti dengan alasan berakhir masa jabatan, pindah tugas, dll;

3. Pendekatan sektoral pembuatan undang-undang lebih kuat dibanding pendekatan sistem;

\footnotetext{
${ }^{5}$ Undang-Undang No. 5 Tahun 1960 tentang Peraturan Pokok Agraria

${ }^{6}$ Undang-Undang No. 25 Tahun 2007 tentang Penanaman Modal

7 Wasis Susetio, "Disharmoni Peraturan Perundang-Undangan di Bidang Agraria" Lex Jurnalica, 03 (Desember,2013), hlm. 142.
} 
Volume 16, Nomor 1, Januari - Juni 2021

4. Kurangnya koordinasi yang dilakukan antar instansi dalam pembentukan perundangundangan;

5. Terbatasnya akses masyarakat dalam pembentukan perundang-undangan;

6. Cara dan metode pembentukan perundang-undangan masih belum dibuat secara mantap, begitupula dengan lembaga yang berwenang membuatnya.

Di berbagai negara dunia, regulasi tentang perizinan cenderung dipermudah dengan regulasi yang tidak berbelit-belit dan lebih efiesien demi mempermudah masuknya investasi untuk persaingan dunia internasional.Di Amerika Serikat regulasi dalam bidang ekonomi, Pemerintah Federasi membuat peraturan yang dijadikan standar sebagai acuan dalam pembentukan peraturan di negara-negara bagian yang telah diberi kewenangan untuk mengatur segala aktifitas komersial di wilayahnya, sehingga aturan pelaksanaaanya berbeda di tiap negara bagian. ${ }^{8}$

Presiden Jokowi pada saat menyampaikan pidato pelantikannya tanggal 20 Oktober 2019, menyampaikan bahwa untuk menyederhanakan dan memangkas segala bentuk regulasi, pemerintah akan membentuk dua Undang-Undang, yaitu Undang-Undang Cipta Lapangan Kerja dan Undang-Undang Pemberdayaan Usaha Makro Kecil dan Menengah (UMKM) menggunakan konsep Omnibus Law yang dapat merubah dan merivisi beberapa aturan hingga puluhan aturan. Konsep Omnibus Law ini merupakan hal yang baru terdengar di Indonesia, namun diharapkan dapat menyelesaikan permasalahanpermasalahan banyaknya peraturan yang tidak sinkron di negara kita.

Omnibus Law yang dapat disebut juga dengan Undang-Undang 'sapu jagat' yang dapat mengganti beberapa norma hukum dalam Undang-Undang terkait, ${ }^{9}$ berbagai peraturan perundang-undangan yang tidak selaras dapat disinkronkan menjadi sebuah Undang-Undang besar yang memuat bidang-bidang tertentu, kemudian memangkas peraturan perundang-undangan lainnya sehingga menjadi lebih efisien dan mempermudah proses pengaturan berbagai hal di Indonesia. Konsep ini ke depan diharapkan dapat membangun harmonisasi perundang-undangan di Indonesia untuk mencapai kepastian hukum.

Namun, konsep ini masih menjadi perdebatan para apabila diterapkan di Indonesia yang menganut sistem civil law yang mengutamakan adanya kodifikasi hukum.Konsep ini merupakan konsep yang baru karena biasanya diterapkan di negara common law, sehingga memerlukan penyesuaian terhadap sistem hukum di negara kita.Ditambah dengan gerak cepat pemerintah yang terkesan terburu-buru dalam membuat Rancangan Undang-Undang Omnibus Law, dikhawatirkan dapat mengabaikan teknis penyusunan perundang-undangan baik secara formil maupun materil.

\footnotetext{
${ }^{8}$ Adrian Sutedi, Hukum Perizinan:Dalam Sektor Pelayanan Publik,(Jakarta:Sinar Grafika,2011), hlm. 339.

${ }^{9}$ Mirza Satria Buana, "Menakar Konsep Omnibus Law dan Consolidation Law untuk Harmonisasi Peraturan Prundang-Undangan Indonesia: Pendekatan Perbandingan Hukum Tata Negara", Prosiding Konferensi Nasional Hukum Tata Negara (KNHTN) Ke-4: Penataan Regulasi di Indonesia, ed., Ghautama Budi Arundati, dkk, (Jember: UPT Penerbitan Universitas Jember, 2017), hlm. 311.
} 
Volume 16, Nomor 1, Januari - Juni 2021

Draft Rancangan Undang-Undang yang telah diserahkan pemerintah kepada DPR pun banyak menimbulkan kontroversi, sebagaimana pada 170 ayat (1) dan (2) yang menyatakan bahwa perubahan Undang-Undang dapat diubah melalui penerbitan Peraturan Pemerintah (PP). Hal ini bertentangan dengan salah satu asas perundangundangan yang patokannya pada hierarki peraturan perundang-undangan dalam UndangUndang No. 15 Tahun 2019.Nah inilah yang menjadi kekhawatiran berbagai pihak, bahwa adanya konsep ini dapatkan menjadi solusi atau malah menimbulkan masalah baru dalam perundang-undangan negara kita.

Dalam penerapan konsep ini, perlu diadakan kajian-kajian mendalam agar tidak merugikan kepetingan rakyat serta diperlukan ahli dan professional untuk mengkualifikasi perundang-undangan yang sejenis yang kemudian dapat mengelompokkan peraturan-peraturan yang saling berkaitan. Serta untuk tujuan harmonisasi perundang-undangan ini juga perlu adanya pemangkasan administrasi dan birokrasi sebagai pendukung terjadi proses yang simple dan efisien.

Menurut Busyroh, ${ }^{10}$ dalam penerapannya konsep ini harus ada pengaturan berupa landasan hukum yang kuat agar tidak bertentangan dengan norma dan peraturan pembentkan perundang-undangan yang teknisnya dengan penerbitan Peraturan Pemerintah Pengganti Undang-Undang (Perppu) misalnya, agar terjadi percepatan penyelesaian masalah regulasi di Indonesia. Jadi, diperlukan adanya perubahan UndangUndang Pemebentukan Peraturan Perundang-Undangan terlebih dahulu sebelum diterapkannya konsep ini.

Jimly memberikan pendapat, meskipun seharusnya dibentuk terlebih dahulu aturan tentang Undang-Undang Omnibus ini, namun dengan tanpa dirubahnya peraturan pembentukan peraturan perundang-undangan pun, konsep ini sudah dapat diterapkan karena selama ini Undang-Undang Pembentukan Perundang-undangan bersifat memandu dan tidak kaku, sehingga dapat saja diterobos yang kemudian membentuk kebiasaan dan ketatanegaraan yang baru sebagai dasar hukum untuk praktik-praktik selanjutnya. ${ }^{11}$

\section{Metode Penelitian}

Penelitian ini adalah penelitian hukum normatif, dengan pendekatan perundangundangan(statue approach), pendekatan perbandingan (comparative approach), dan pendekatan konseptual(conseptual approach). Sumber data berupa data primer dan data sekunder yang diperoleh melalui studi kepustakaan (library research). Analisa yang digunakan adalah diskriptif kualitatif.

\section{Pembahasan}

Pembahasan dan analisis dalam artikel bertujuan untuk menjawab rumusan masalah dan pertanyaan-pertanyaan penelitian, menunjukkan bagaimana temuan-temuan

\footnotetext{
${ }^{10}$ Firman Freaddy Busyroh, "Konseptualisasi Omnibus Law dalam Menyelesaikan Permasalahan Regulasi Pertanahan", Arena Hukum Volume 10, 2, (Agustus 2017), hlm. 248.

11 Jimly Asshidieqie, Undang-Undang Omnibus (Omnibus Law), Penyederhanaan Legislasi, dan Kodifikasi Administratif, tt, hlm. 3.
} 
Volume 16, Nomor 1, Januari - Juni 2021

itu diperoleh, menerangkan arti hasil penelitian, bagaimana hasil penelitian dapat memecahkan masalah serta kemungkinan pengembangannya. Pembahasan dan analisis harus menjawab permasalahan dan tujuan penelitian. Pembahasan dalam tulisan ini mencakup konsep Omnibus law dalam membangun harmonisasi peraturan perundang-undangan di Indonesia dan hambatan-hambatan yang dialami apanila kondep ini diterapkan di Indonesia.

\section{Pengertian Konsep Omnibus Law}

Istilah Omnibus berasal dari sebutan sebuah bus yang dapat mengangkut banyak orang dan barang-barang lainnya yang disebut dengan "Bus Omni."Bus ini pertama kali beroperasi di Paris pada Tahun 1820.Namun ketika sudah dipakai di Amerika Latin, istilah ini menjadi generic sehingga segala sesuatu yang bisa dimasuki berbagai hal disebut Omnibus.Begitupun dalam bidang hukum yang kemudian disebut Omnibus Law yaitu suatu Undang-Undang yang mencakup beberapa Undang-Undang yang terkait. ${ }^{12}$

Omnibus Law terdiri dari dua kata yaitu Omnibus yang memiliki arti semuanya, istilah ini berasal dari bahasa latin. ${ }^{13}$ Dalam Black Law Dictionary Ninth Editon kata Omnibus adalah relating to or dealing with numerous objects or item at once; including many things or having various purpose, ${ }^{14}$ yang berarti berkaitan dengan beragam objek atau item sekaligus;termasuk banyak hal atau memiliki berbagai tujuan. Sedangkan kata Law secara bahasa maknanya adalah hukum. Apabila digandengkan kedua istilah tersebut maka Omnibus Law yaitu hukum untuk semuanya. Omnibus Law sering juga disebut dengan istilah Omnibus Bill yang berarti:

1. A single bill containing various distinct matters, usu. Drafted in this to force the executive either to accept all the unrelated minor provisions or to veto the major provision. 2. A bill that deals with all proposals relating to a particular subject, such as an "omnibus judgeship bill" covering all proposals for new judgeship or an "omnibus crime bill" dealing with different subjects such as new crimes and grants to states for crime control. ${ }^{15}$

Secara singkat dapat dimaknai bahwa Omnibus Law atau Omnibus Bill adalah sebuah aturan yang memuat berbagai kedaan yang berbeda dan dapat merubah berbagai aturan.Menurut Usfunan secara sederhana Omnibus law adalah sebuah metode penyusunan aturan yang mana di dalamnya terdapat beberapa materi subtansi, dan ketika diundangkan, peraturan ini dapat mencabut materi dari peaturan-peraturan sebelumnya. ${ }^{16}$

\footnotetext{
${ }^{12}$ Dahlan Iskan, "Terminal Omni," DI's Way, Desember 2019, accessed June 13, 2020, https://www.disway.id/r/767/terminal-omni.

${ }^{13}$ Firman Freddy Busroh, "Konseptualisasi Omnibus Law Dalam Menyelesaikan Permasalahan Regulasi Pertanahan” Vol.10, No. 2 (Agustus 2017): hlm. 227-250.

${ }^{14}$ Bryan A. Garner, "Black's Law Dictionary" (United States of America: Thomson Reuters, 2009), epdf.pub_blacks-lawldictionary.pdf.1197.

${ }^{15}$ Ibid. 186.

${ }^{16}$ Jimmy Z. Usfunan, "Menata Undang-Undang Dengan Omnibus Law," Hukum Online, Desember 2017, accessed April 5, 2020, https://m.hukumonline.com/berita/baca/lt5a28e1bb91cc6/menataundang-undang-dengan-omnibus-law-oleh-jimmy-z-usfunan/.
} 
Volume 16, Nomor 1, Januari - Juni 2021

Jimly, menyatakan bahwa UU Omnibus merupakan format pembentukan undangundang yang bersifat menyeluruh dengan turut mengatur materi undang-undang lainnya yang berkaitan dengan subtansi undang-undang yang akan dibentuk atau diubah, yaitu pembentukan satu undang-undang dengan mempertimbangkan ketentuan-ketentuan dari beberapa undang-undang yang saling berkaitan. ${ }^{17}$

Pengertian Omnibus law ini juga disampaikan oleh Pakar Hukum Widiati, bahwa Omnibus law merupakan teknik perancangan yang menggabungkan beberapa perundangundangan yang bertujuan untuk meningkatkan aksesibilitas perundang-undangan yang kedudukannya sama dengan undang-undang lainnya. ${ }^{18}$

Mencermati beberapa pengertian yang disampaikan para pakar di atas, dapat disimpulkan bahwa Omnibus law adalah sebuah konsep pembentukan perundangundangan, dimana sebuah undang-undang yang dibentuk untuk memuat beberapa materi/substansi dari berbagai aturan lainnya yang berkaitan dengan aturan yang dibentuk, dan undang-undang ini dapat merubah atau mencabut undang-undang sebelumnya. Omnibus law juga disebut dengan undang-undang 'sapu jagat' yang dapat mengganti norma hukum dalam beberapa undang-undang. ${ }^{19} \mid \mathrm{Dalam}$ praktek di Indonesia yang menganut civil law kita juga mengenal kodifikasi hukum, undang-undang pokok, dan undang-undang payung. Kodifikasi hukum adalah pengelompokkan undang-undang sejenis atau memiliki materi yang sama untuk mendapat suatu rechtseenheid (kesatuan hukum) dan suatu rechtszakerheid (kepastian hukum). ${ }^{20}$ Menurut Satjipto Rahardjo, kodifikasi hukum bertujuan untuk mempermudah menguasai peraturan-peraturan, menjadikan lebih sederhana, tersusun secara logis, dan pasti. ${ }^{21}$

Undang-undang payung atau disebut juga Umbrella Act ialah undang-undang yang menjadi payung dari anak Undang-Undang tersebut, begitu pula dengan undangg-undang pokok yang menjadi pokok atau acuan dari aturan-aturan lainnya yang berkaitan. ${ }^{22}$ Menurut Busyroh, konsep omnibus law karena mengatur secara menyeluruh serta memiliki kekuatan terhadap lainnya. ${ }^{23}$ Salah satu contohnya adalah Undang-Undang

\footnotetext{
${ }^{17}$ Jimly Asshiddiqie, "UU Omnibus (Omnibus Law) Penyederhanaan Legislasi, Dan Kodifikasi Administratif," 2019, accessed April 4, 2020, UU TERPADU (Omnibus Law).pdf.diakses April 4, 2020.

${ }^{18}$ Aditya Novrian, "Pakar Hukum UNAIR Sebut Omnibus Law Produk Hukum Yang Lebih Kompleks," UNAIR NEWS (Surabaya, February 11, 2020), http://news.unair.ac.id/2020/02/11/pakar-hukum-unair-sebut-omnibus-law-produk-hukum-yanglebih-kompleks/.diakses 5 April 2020.

${ }^{19}$ Mirza Satria Buana, "Menakar Omnibus Law Dan Consolidation Law Untuk Harmonisasi Peraturan Perundang-Undangan Indonesia: Pendekatan Perbandingan Hukum Tata Negara," in Penataan Regulasi Di Indonesia (presented at the Konferensi Nasional Hukum Tata Negara Ke-4, Jember: UPT Penerbitan Universitas Jember, 2017).

${ }^{20}$ R. Soeroso, Pengantar Ilmu Hukum (Jakarta: Sinar Grafika, 2011). hlm. 77.

${ }^{21}$ Satjipto Rahardjo, Ilmu Hukum (Bandung: PT. Citra Aditya Bakti, 1991). hlm. 92.

${ }^{22}$ Tim Penysun Kajian Dewan Mahasiswa Justicia Fakultas Hukum UGM, "Pembahasan Formil," Sebuah Kajian Mengupas Omnbus Law Bikin Ga(k)Law, 2020, accessed March 21, 2020, Mengupas-Omnibus-Law-Bikin-GakLaw-8.pdf.

23 Firman Freddy Busroh, "Konseptualisasi Omnibus Law Dalam Menyelesaikan Permasalahan Regulasi Pertanahan.” hlm. 246.
} 
Volume 16, Nomor 1, Januari - Juni 2021

No.5 Tahun 1960 tentang Pokok Agraria (UUPA) yang berlaku sebagai induk dari undang-undang sumber daya alam dan petanahan lainya. Namun, dalam hierarki peraturan perundang-undangandi Indonesia tidak terdapat istilah undang-undang pokok maupun undang-undang payung, yang ada hanya "Undang-Undang." Dengan dmikian undang-undang pokok maupun undang-undang payung sama saja dengan undang-undang lainnya.

Konsep Omnibus law ini secara tidak langsung pernah diterapkan di Indonesia, namun tidak dalam bentuk undang-undang tetapi Ketetapan Majelis Permusyawaratan Rakyat N0. 1 Tahun 2003 (TAP MPR No. 1/2003) yang disebut dengan “Tap sapujagat" karena dengan adanya TAP MPR ini menutup semua Tap-Tap MPR yang bersifat mengatur, yang berarti tidak boleh ada lagi TAP MPR yang bersifat mengatur. ${ }^{24}$

Kemudian dalam Peraturan Pemerintah Pengganti Undang-Undang No. 1 Tahun 2017 tentang Akses Informasi Keungan untuk Kepentingan Perpajakan yang telah diubah menjadi Undang-Undang No. 9 Tahun 2017 merupakan salah satu praktek yang dapat dikatakan mirip dengan konsep omnibus law karena dengan diundangkannya UndangUndang ini, maka dalam Pasal 8 Undang-Undang ini mencabut beberapa Undang-Undang sebelumnya yang berkaitan dengan akses informasi keuangan dan kepentingan untuk perpajakan.

Dalam Undang Undang No. 32 Tahun 2014 tentang Pemerintahan Daerah juga dijelaskan bahwa pemerintah pusat berwenang untuk menentukan norma sebagai pedoman dalam penyelenggaraan pemerintahan sehingga dapat mempemudah dan mencegah penyimpangan dalam pelaksanaan Pemerintah Daerah. ${ }^{25}$

\section{Urgensi Harmonisasi Perundang-Undangan dalam Pembangunan Hukum di Indonesia}

Kata harmoisasi menurut Kamus Besar Bahasa Indonesia artinya adalah upaya mencari keselarasan, ${ }^{26}$ yang berarti harmonisasi adalah mencari kesesuaian dan keselarasan. Lebih lanjut A.A. Oka Mahendra memaparkan pengharmonisasian adalah upaya untuk mengharmoniskan atau menyelaraskan. ${ }^{27}$ Menurut Prof. Ahmad M. Ramli harmonisasi berasal dari kata harmoni yang berarti keselarasan, kecocokan, keserasian. Unsur-unsur yang dapat ditarik dari pengertian harmonisasi di atas adalah: ${ }^{28}$

1. Adanya hal-hal yang bertentangan, kejanggalan;

\footnotetext{
${ }^{24}$ Moh. Mahfud MD, Politik Hukum Di Indonesia, Revisi. (Jakarta: Rajawali Pers, 2014). hlm. 376.

${ }^{25}$ Undang-Undang No. 23 Tahun 2014 Tentang Pemerintahan Daerah, n.d.

${ }^{26}$ Kemendikbud, "KBBI Daring," KBBI (Jakarta: Badan Pengembangan dan Pembinaan Bahasa, 2016), accessed April 24, 2020, kbbi.kemendikbud.go.id.

${ }^{27}$ A.A Oka Mahendra, Reformasi Pembangunan Dalam Perspektif Perundang-Undangan (Jakarta: Departemen Hukum dan HAM, 2006).hlm.360.

${ }^{28}$ Wahiduddin Adams, "Harmonisasi Peraturan Perundang-Undangan Di Indonesia," in Dialektika Pembaruan Sistem Hukum Indonesia (Jakarta: Sekretariat Jenderal Komisi Yudisial Republik Indonesia, 2012).hlm.140.
} 
Volume 16, Nomor 1, Januari - Juni 2021

2. Menyelaraskan suatu hal-hal yang bertentangan agar membentuk suatu sistem;

3. Suatu proses atau suatu upaya untuk merealisasi keselarasan, kesesuaian, keserasian, kecocokan, dan keseimbangan; dan

4. Kerjasama antara berbagai faktor yang sedemikian rupa, hingga faktor-faktor tersebut menghasilkan kesatuan.

Dari beberapa pengertian di atas dapat disimpulkan makna harmonisasi sebagai upaya untuk menyelaraskan, memadukan, mencocokkan, menyerasikan, dan menyeimbangkan hal-hal yang bertentangan sehingga menjadi sebuah sistem yang baik.

Jika dikaitkan dengan kata hukum, harmonisasi hukum yaitu sebuah kegiatan ilmiah untuk menuju proses penyelarasan hukum tertulis yang mengacu pada nilai-nilai filosofis, sosiologis, ekonomis maupun yuridis, yang dalam pelaksanaannya adalah pengkajian secara komprehensif terhadap suatu rancangan undang-undang yang bertujuan untuk mengetahui bahwa undang-undang tersebut telah selaras dan sesuai dengan hukum yang telah berlaku baik yang tertulis maupun tidak tertulis dalam berbagai aspek. ${ }^{29}$

Pengharmonisasian peraturan perundang-undangan ini dilakukan dengan tujuan untuk:

1. Mengkoordinasikan antar kementerian, kelembagaan, dan masyarakat untuk menampung usulan dan masukan demi penyempurnaan peraturan perundangundangan yang dibentuk;

2. Mewujudkan peraturan perundang-undangan yang sesuai dengan dengan masa kini dan dapat diterapkan; dan

3. Mewujudkan peraturan perundang-undangan yang serasi, aspiratif,responsif, taat asas, selaras secara vertikal maupun horizontal. ${ }^{30}$

Upaya pengharmonisasian ini dilakukan untuk mendukung pembangunan hukum nasional di Indonesia menjadi lebih baik. Pembangunan hukum nasional dapat terwujud dengan syarat pembentukan peraturan perundang-undangan dengan baik dan benar, serta menggunakan standar metode yang jelas, baku, pasti dan dapat mengikat semua lembaga yang berhak membentuk peraturan perundang-undangan. ${ }^{31}$

Selain menggunakan metode dengan standar yang jelas, penerapan asas-asas peraturan perundang-undangan serta kegiatan penelitian dan pengembangan juga sangat penting.Dengan diterapkannya asas-asas yang berlakuyang dapat menghasilkan peraturan perundang-undangan baik dan sesuai dengan kebutuhan masyarakat.

Namun pada prakteknya sampai saat ini masih banyak sekali terdapat berbagai peraturan perundang-undangan yang tidak harmonis dan tumpang tindih sehingga

\footnotetext{
${ }^{29}$ Moh. Hasan Wargakusumah, Perumusan Harminisasi Hukum Tentang Metodologi Harmonisasi Hukum (Jakarta: Bada Pembinaan Hukum Nasional Departemen Kehakiman, 1997). hlm. 37.

${ }^{30}$ Wahiduddin Adams, "Harmonisasi Peraturan...... hlm. 143.

${ }^{31}$ Jimly Asshiddiqie, "Perihal Undang-Undang," December 2, 2019, Perihal UU-Jimly.pdf (SECURED).hlm.261.
} 
Volume 16, Nomor 1, Januari - Juni 2021

menyebabkan sulitnya kepastian hukum dan dapat menghambat iklim investasi di Indonesia.

Penghambatan iklim investasi di Indonesia disebabkan oleh berbelit-belitnya perizinan yang harus dilewati oleh para investor.Hal ini disebabkan banyaknya peraturanperaturan dalam bidang perizinan.pada tahun 2016 saja terdapat kurang lebih 180 peraturan tentang perizinan di daerah yang pada intinya sama, hanya saja dengan penyebutan yang berbeda. ${ }^{32}$

Pemerintah telah melakukan beberapa upaya untuk mengurangi dan mempermmudah perizinan dengan menerapakan Pelayanan Terpadu Satu Pintu (PTSP) sejak tahun 2015 yaitu pelayanan perizinan maupun non perizinan yang dilakukan dalam satu tempat mulai proses permohonan sampai terbitnya dokumen dalam satu tempat, sehingga dapat mempersingkat waktu pengurusan.

Tidak samapai disini saja usaha pemerintah dalam menanggulangi permasalahan ini, kemudian pemerintah gencar membenahi aturan-aturan yang berkaitan dengan memangkas peraturan-peraturan mealalui Paket Kebijakan Ekonomi (PKE) yang dilaksanankan dengan Peraturan Presiden Nomor 91 Tahun 2017 tentang Percepatan Pelaksanaan Berusaha. Kemudian disusul dengan dikeluarkannya Peraturan Pemerintah Nomor 24 Tahun 2018 tentang Pelayanan Perizinan Berusaha Terintegrasi Secara Elektronik atau dikenal dengan sebutan Online Single Submission (OSS). Suatu system elektronik yang terintegrasi yang telah memangkas peraturan perizinan sebanyak 537 menjadi 237 izin dan 362 menjadi 215 non izin. ${ }^{33}$ Namun berbagai usaha yang telah dilakukan pemerintah masih belum mendapatkan hasil yang maksimal, sehingga diperlukan terobosan-terobosan lain untuk menyelesaikannya.

Dengan demikian, harmonisasi peraturan perundang-undangan sangat penting dilakukan di Indonesia demi mencapai pembangunan hukum yang baik dan sesuai dengan kepentingan rakyat.Presiden Jokowi menyampaikan bahwa untuk menangani permasalahan disharmonisasi peraturan perundang-undangan yang dapat menimbulkan ketidakpastian hukum serta menghambat investasi dapat ditangani dengan penerapan konsep omnibus law yang dapat memangkas beberapa peraturan perundang-undangan menjadi sebuah undang-undang besar, yang telah diterapkan di beberapa negara dunia, sehingga dapat mempermudah investasi di Indonesia.

Upaya yang dilakukan dengan gagasan penerapan konsep omnibus law yang digadang-gadangkan dapat menyelesaikan permasalahan tumpang tindihnya peraturan perundang-undangan ini masih memerlukan kajian mendalam karena merupakan istilah yang baru dikenal di negara kita dan memerlukan penyesuaian terhadap sistem hukum Indonesia.

\section{Hambatan-Hambatan Penerapan Gagasan Omnibus Law Indonesia}

\footnotetext{
${ }^{32}$ Naskah Akademik RUU Cipta Kerja.hlm.15

${ }^{33}$ Pemerintah Nomor 24 Tahun 2018 tentang Pelayanan Perizinan Berusaha Terintegrasi Secara Elektronik
} 
Volume 16, Nomor 1, Januari - Juni 2021

Konsep ini telah diterapkan di bebagai negara yang menganut sistem hukum common law sebagai solusi penyederhanaan regulasi.Indonesia yang merupakan negara penganut sistem hukum civil law masih baru mengenal istilah omnibus law sebagai solusi permasalahan disharmonisasi peraturan perundang-undangan.Dengan demikian perlu dilakukan kajian mendalam dalam penerapan konsep ini dengan mencermati dan mempertimbangkan serta menyesuaikan berbagai hal yang berkaitan dengan regulasi. Hambatan utama yang perlu dicermati sebelum diterapakan konsep ini sesuai dengan sistem hukum di Indonesia adalah:

1. Penyesuaian Terhadap Sistem Hukum Indonesia

Konsep omnibus law ini belum pernah secara langsung diterapkan di Indonesia dengan negara hukum yang menganut sistem hukum civil law yang mengutamakan kodifikasi hukum untuk keberlakuan hukum yang lebih efektif sesuai dengan politik hukum yang diinginkan. ${ }^{34}$ Konsep omnibus law ini biasanya diterapkan di negara-negara common law yangmengutamakan preseden sebagai sumber hukum, sehingga kodifikasi hukum tidak menjadi hal yang utama dan hakim dalam mengambil keputusan tidak menjadikan sebuah peraturan perundang-undangan sebagai patokan utama. Berbeda dengan di Indonesia, dimana peraturan perundangundangan adalah utama dan hakim dalam memutuskan perkara disesuaikan dengan peraturan perundang-undangan yang berlaku demi tercapainya kepastian hukum.

Dengan demikian, tidak mudah bagi Indonesia yang pernah dijajah Belanda yang menganut sistem hukum civil law untuk menerapkan sebuah sistem yang biasa diterapkan di negara-negara common law yang memberikan porsi lebih terhadap putusan hakim terdahulu.

Namun belakangan ini, terjadi konvergensi antara dua sistem hukum tersebut, dimana di negara common law mulai memberikan ruang untuk pembentukan undangundang dan begitu sebaliknya di negara civil law menggunakan yurisprudensi sebagai sumber hukum, bahkan di Belanda juga telah menerapkan metode omnibus law sejak tahun $2006 .^{35}$

2. Tidak Ada Landasan Hukum yang Jelas

Omnibus law di Indonesia belum memiliki landasan hukum yang jelas karena dalam hierarki peraturan perundang-undangan yang tercantum dalam Pasal 7 maupun pasal 8 Undang-Undang No. 15 Tahun 2019 tentang Pembentukan Peraturan Perundang-Undangan tidak dijelaskan tentang konsep ini yang menyebabkan timbulnya kesulitan-kesulitan dalam teknik penyusunan, pembahasan, dan penerapannya dikarenakan tidak adanya landasan hukum.

Namun, sebelumnya Indonesia pernah menerapkan Undang-Undang Pokok atau disebut juga Undang-Undang Payung misalnya Undang-Undang No. 5 Tahun 1960 tentang Pokok-Pokok Agraria yang dijadikan acuan terhadap aturan-aturan

\footnotetext{
${ }^{34}$ Tim Penysun Kajian Dewan Mahasiswa Justicia Fakultas Hukum UGM, "Pembahasan Formil.". hlm. 5 .

${ }^{35}$ Ibid.,
} 
Volume 16, Nomor 1, Januari - Juni 2021

lainnya yang terkait namun belakangan dalam penerapannya belum dapat menjadi aturan pokok untuk penerapan peraturan-peraturan yang berkaitan. Dalam hierarki perundang-undangan di Indonesia kedudukan Undang-Undang Payung maupun Undang-Undang Pokok sama dengan undang-undang.

Dengan demikian secara normatif konsep omnibus law ini sah diterapkan di Indonesia karena sesuai dengan hierarki peraturan perundang-undangan negara kita serta tidak ada larangan dalam Undang-Undang Pembentukan Peraturan Perundangundangan untuk menerapkan konsep ini.Sehingga dalam penerapannya konsep omnibus law dianggap sah secara formil.Begitupula dalam pembentukkannya harus disesuaikan dengan teknik pembentukan Undang-Undang baik secara formal maupun materil. Ada beberapa langkah yang harus dipenuhi dalam pembentukan omnibus law ini, yaitu: ${ }^{36}$

a.Pembentuk Undang-Undang dalam hal ini Presiden dan DPR harus melibatkan banyak pihak dalam pembentukan omnibus law ini, mengingat sangat luas halhal yang akan dibahas. Dengan demikian memelukan banyak pendapat ahli-ahli dalam bidangnya serta partisipasi masyarakat yang memiliki kepentingan terhadap aturan baru yang akan dibentuk.

b. Pemerintah dan DPR harus lebih transparan dalam transparansi perkembangan dalam proses pembentukan Undang-Undang ini agar tidak terjadi masalah kedepannya. Berkaca dengan beberapa Undang-Undang kontroversi sebelumnya seperti Revisi Undang-Undang Pemberantasan Korupsi dan Revisi Kitab Undang-Undang Hukum Pidana yang menimbulkan berbagai permasalahan karena kurangnya transparansi pembentuk Undang-Undang terhadap publik.

c.Dalam penyusunannya konsep ini harus memetakan berbagai peraturan perundang-undangan secara rinci karena banyaknya aturan-aturan yang akan dirubah dan dibahas dari bebagai sektor. banyak tenaga ahli hukum profesional dan sistem audit elektronik yang khusus dikembangkan untuk penataan regulasi di Indonesia. ${ }^{37}$

d. Harmonisasi harus dilakukan secara ketat baik secara vertikal maupun horizontal, agar tidak menyalahi asas-asas peraturan perundang-udangan.

e.Sebelum disahkan Undang-Undang ini harus dilakukan preview untuk melihat dampak yang akan terjadi apabila omnibus law sudah diterapkan.

Dalam pembentukan Undang-Undang dengan konsep omnibus law, secara formil harus memperhatikan berbagai asas-asas pembentukan peraturan perundang-undangan sebagaimana disebutkan dalam Pasal 5 Undang-Undang No. 15 Tahun 2019, yaitu:

\footnotetext{
${ }^{36}$ Agnes Fitryantica, "Harmonisasi Peraturan Perundang-Undangan Indonesia Melalui Konsep Omnibus Law," Gema Keadilan Volume 6 Edisi III (Oktober 2019). hlm. 313.

${ }^{37}$ Asshiddiqie, "UU Omnibus (Omnibus Law) Penyederhanaan Legislasi, Dan Kodifikasi Administratif.", hlm. 8.
} 
Volume 16, Nomor 1, Januari - Juni 2021

a.Kejelasan tujuan, pembentukan Undang-Undang dengan konsep omnibus law bertujuan untuk memangkas peraturan perundang-undangan yang sangat banyak di Indonesia agar dapat mempermudah proses investasi dan perizinan.

b. Kelembagaan atau pejabat pembentuk Undang-Undang-Undang yang tepat, Undang-Undang omnibus law diusulkan oleh Presiden sebagai salah satu lembaga yang berwenang dalam pembentukan Undang-Undang yang kemudian diberikan kepada DPR untuk dibahas.

c.Dapat dilaksanakan, setiap pembenukan Undang-Undang harus dipertimbangkan kelak dapat dilaksanakan dengan baik ataupun tidak.

d. Kedayagunaan dan kehasilgunaan, setiap peraturan perundang-undangan yang dibuat memang dibutuhkan dan bermanfaat dalam mengatur kehidupan masyarakat.

e.Keterbukaan, dalam pembentukan peraturan perundang-undangan harus transpran, mulai dari perencanaann, penyusunan, pembahasan, pengesahan sampai pada penetapannya. Dalam pembentukan Undang-Undang dengan konsep ini terkesan terburu-buru sehingga dapat mengabaikan asas ini.

\section{Ketidakjelasan kedudukan jenis Peraturan Perundang-undangan}

Undang-Undang No. 15 Tahun 2019 tentang Pembentukan Peraturan Perundangundangan diatur teknik tentang perubahan Undang-Undang dengan pembentukan Undang-Undang baru berbeda yang berbunyi:

Jika suatu perubahan Peraturan Perundang-undangan mengakibatkan:

a.Sistematika Peraturan Perundang-undangan berubah;

b. Materi Peraturan Perundang-undangan berubah lebih dari 50\% (lima puluh persen); atau

c.Esensinya berubah.

Peraturan Perundang-undangan yang dirubah tersebut lebih baik dicabut dan disusun kembali dalam Peraturan Perundang-undangan yang baru mengenai masalah tersebut.

Dalam pembentukannya Undang-Undang omnibus ini juga perlu dipastikan merupakan Undang-Undang yang baru atau Undang-Undang perubahan.Karena apabila Undang-Undang ini merupakan perubahan materinya hanya berisi pencabutan, penggantian atau penambahan materi pokok dari Undang-Undang sebelumnya. Apabila perubahan yang dilakukan lebih dari lima puluh persen dan esensinya berubah, maka sebaiknya dilakukan pembentukan Undang-Undang yang baru untuk membahas masalah tersebut. 
Volume 16, Nomor 1, Januari - Juni 2021

Dalam Rancangan Undang-Undang Cipta Kerja Pasal 17 dan 18 yang telah disusun pemerintah dan kemudian diserahkan ke DPR, Undang-Undang ini merupakan UndangUndang Perubahan yang berbunyi: ${ }^{38}$

\section{Pasal 17}

Dalam rangka penyederhanaan persyaratan dasar Perizinan Berusaha serta untuk memberikan kepastian dan kemudahan bagi Pelaku Usaha dalam memperoleh kesesuaian kegiatan pemanfaatan ruang, Undang-Undang ini mengubah, menghapus, dan/atau menetapkan pengaturan baru beberapa ketentuan yang...

\section{Pasal 18}

Beberapa ketentuan dalam Undang-Undang Nomor 26 tahun 2007 tentang Penataan Ruang (Lembaran Negara Republik 15 Indonesia Nomor 68, Tambahan Lembaran Negara Republik Indonesia Nomor 4725) diubah....

Hal inilah yang menyebabkan tidak ada kejelasan status Undang-Undang dengan konsep omnibus law ini sebagai sumber hukum. ${ }^{39}$ Apabila Rancangan Undang-Undang ini dianggap sebagai Undang-Undang baru tetapi materi yang dimuat adalah tentang Undang-Undang perubahan, maka teknik pembentukannya tidak sesuai dengan lampiran Undang-Undang Pembentukan Peraturan Perundang-Undangan.

Setelah kita cermati berbagai permasalahan kontradiksi Undang-Undang dengan konsep omnibus law dengan Undang-Undang Pembentukan Peraturan Perundangundangan maka, untuk menanggulangi masalah ini dapat dilakukan alternatif yaitu dengan merubah Undang-Undang No. 15 Tahun 2019 tentang Pembentukan Peraturan Perundang-undangan, karena Undang-Undang inilah yang menentukan sah atau tidaknya suatu Undang-Undang dengan teknik pembentukan peraturan perundang-undangan yang diatur di dalamnya. Namun harus diperhatikan juga urgensi dari perubahan UndangUndang ini karena di tahun 2019 baru saja Undang-Undang ini dirubah dan apabila dirubah lagi akan menjadi perubahan yang ketiga. ${ }^{40}$

Alternatif lainnya yang dapat dilakukan yaitu dengan merubah secara formil maupun muatan dari hal-hal yang bertentangan dalam Undang-Undang Omnibus ini dengan Undang-Undang tentang Pembentukan Peraturan Perundang-undangan sesuai dengan yang telah dipaparkan dalam lampiran Rancangan Undang-Undang Cipta Kerja bahwa apabila ada yag bertenangan dengan Undang-Undang Pembentukan Peraturan Perundang-Undangan, maka dapat dicabut maupun dihapus dan disesuaikan dengan aturan yang berlaku. ${ }^{41}$

3. Sulitnya Perumusan Ketentuan Umum

\footnotetext{
38 Pasal 17 dan 18 Rancangan Undang-Undang Cipta Kerja

${ }^{39}$ Tim Penysun Kajian Dewan Mahasiswa Justicia Fakultas Hukum UGM, "Pembahasan Formil."'hlm.12

${ }^{40}$ Ibid., hlm. 13

${ }^{41}$ Ibid.
} 
Ketentuan umum merupakan salah satu bagian dari batang tubuh Undang-Undang yang terletak di awal yang berisi tentang batasan pengertian atau definisi, singkatan atau akronim yang akan digunakan dalam peraturan, dan hal-hal lain yang bersifat umum misalnya tentang asas, maksud dan tujuan Undang-Undang tersebut dibentuk. ${ }^{42}$

Perumusan ketentuan umum ini menjadi perhatian karena konsep omnibus law ini merupakan Undang-Undang yang mencakup beberapa Undang-Undang yang dijadikan satu, sehingga berpotensi adanya ketidakserasian ketentuan umum yang digeneralisasi dari berbagai Undang-Undang. Sebgaimana urutan kata atau istilah yang terdapat dalam ketentuan umum mengikuti ketentuan sebagai berikut: ${ }^{43}$

a.Pengertian yang ditempatkan lebih dahulu yaitu yang bersifat umum, sedangkan yang bersifat khusus diletakkan kemudian;

b. Pengertian yang terdapat dalam materi pokok lebih dahulu maka diatur dan ditempatkan lebih dahulu urutannya; dan

c.Pengertian yang berkaitan diletakkan berdekatan.

Namun apabila ketentuan umum dipilah-pilah sesuai dengan bidangnya maka potensi ketidakserasian ketentuan umum tidak akan terjadi. Hal ini dapat dilihat dalam Undang-Undang Cipta Kerja, penempatan ketentuan umum masing-bidang diletakkan terpisah, karena Undang-Undang ini menggunakan struktur Undang-Undang perubahan bukan Undang-Undang yang baru.

\section{PENUTUP}

\section{Kesimpulan}

Harmonisasi peraturan perundang-undangan memang sangat penting dilakukan untuk menanggulangi permasalahan tumpang tindihnya peraturan perundang-undangan yang dapat menghmbat investasi. Presiden Jokowi dalam pidatonya menyatakan untuk menanggulangi tumpang tindihnya peraturan perundang-undangan yang menghambat investasi dengan menerapkan konsep omnibus law yang diadopsi dari negara-negara common law. Namun kemudian terjadi pro dan kontra dalam penerapannya di Indonesia yang menganut sistem civil law dan merupakan hal yang baru dalam tatanan peraturan perundaang-undangan. Konsep ini diharapkan dapat menata peraturan perudangundangan yang tumpang tindih sehingga dapat mewujudkan pembangunan hukum nasional sesuai dengan politik hukum yang diinginkan.

Upaya penerapan konsep ini di Indonesia mengalami beberapa hambatan yaitu: Pertama, konsep ini baru pertama kali diterapkan di Indonesia yang membutuhkan kajian yang mendalam dalam penerapannya. Kedua, dalam hierarki peraturan perundangundangan di Indonesia belum pernah diatur mengenai konsep omnibus law, sehingga konsep ini masih belum memiliki landasan hukum.Ketiga, tidak ada kejelasan mengenai

\footnotetext{
${ }^{42}$ Maria Farida Indrati Maria Farida Indrati Soeprapto, Ilmu Perundang-Undangan 2: Proses Dan Teknik Pembentukannya (Yogyakarta: Kanisius, 2019). hlm. 122.

${ }^{43}$ Ibid., hlm. 123.
} 
Volume 16, Nomor 1, Januari - Juni 2021

kedudukan jenis Undang-Undang yang digunakan apakah menggunakan teknik penyusunan Undang-Undang perubahan atau Undang-Undang baru.Dan yang kelima yakni sulitnya dalam perumusan ketentuan umum dikarenakan Undang-Undang ini menghimpun beberapa Undang-Undang menjadi sebuah Undang-Undang yang besar.

\section{Saran}

Upaya penerapan konsep omnibus law di Indonesia ini memang sangat baik apabila benar-benar dapat menyelesaikan permasalahan diharmonisasi peraturan perundangundangan di Indonesia. Namun konsep ini masih baru yang membutuhkan kajian mendalam untuk dapat diterapkan di Indonesia dengan sistem hukum yang ada.Dalam penerapan sebuah peraturan perundang-undangan harus memenuhi asas-asas peraturan perundang-undangan yang berlaku dan tidak merugikan kepentingan warga negara demi kepentingan pribadi maupun golongan.

\section{Daftar Pustaka}

\section{Buku:}

Wahiduddin Adams, "Harmonisasi Peraturan Perundang-Undangan Di Indonesia." In Dialektika Pembaruan Sistem Hukum Indonesia. Jakarta: Sekretariat Jenderal Komisi Yudisial Republik Indonesia, 2012.

Oka Mahendra, A.A. Reformasi Pembangunan Dalam Perspektif Perundang-Undangan. Jakarta: Departemen Hukum dan HAM, 2006.

Moh. Mahfud MD, Politik Hukum Di Indonesia.Revisi. Jakarta: Rajawali Pers, 2014.

Sobhi. Mahmassani, Filsafat Hukum Dalam Islam Terjemahan Ahmad Sudjono.Cet. kedua. Bandung: ALMAARIF, 1981.

Satjipto. Rahardjo, Ilmu Hukum. Bandung: PT. Citra Aditya Bakti, 1991.

Maria Farida Indrati Soeprapto, Ilmu Perundang-Undangan 2: Proses Dan Teknik Pembentukannya. Yogyakarta: Kanisius, 2019.

Soeroso, R. Pengantar Ilmu Hukum. Jakarta: Sinar Grafika, 2011.

Hasan.Wargakusumah, Moh. Perumusan Harminisasi Hukum Tentang Metodologi Harmonisasi Hukum. Jakarta: Bada Pembinaan Hukum Nasional Departemen Kehakiman, 1997.

Jimly Asshiddiqie, "Perihal Undang-Undang," December 2, 2019. Perihal UU-Jimly.pdf (SECURED). 
Volume 16, Nomor 1, Januari - Juni 2021

\section{Artikel Jurnal:}

Fitryantica, Agnes. "Harmonisasi Peraturan Perundang-Undangan Indonesia Melalui Konsep Omnibus Law."Gema Keadilan Volume 6 Edisi III (Oktober 2019).

Syamsoni, Ujang Ruhyat. "TAQNIN AL-AHKAM (Legislasi Hukum Islam Ke Dalam Hukum Nasional)."Nur El-Islam Volume 2 Nomor 2, no.Taqnin al-Ahkam (Oktobe 2015).

\section{Kertas Kerja:}

Asshiddiqie, Jimly. "UU Omnibus (Omnibus Law) Penyederhanaan Legislasi, Dan Kodifikasi Administratif," 2019. Accessed April 4, 2020.UU TERPADU (Omnibus Law).pdf.

\section{Prosiding:}

Buana, Mirza Satria. "Menakar Omnibus Law Dan Consolidation Law Untuk Harmonisasi Peraturan Perundang-Undangan Indonesia: Pendekatan Perbandingan Hukum Tata Negara." In Penataan Regulasi Di Indonesia. Jember: UPT Penerbitan Universitas Jember, 2017.

Busroh, Firman Freddy. "Konseptualisasi Omnibus Law Dalam Menyelesaikan Permasalahan Regulasi Pertanahan” Vol.10, No. 2 (Agustus 2017): 227-250.

Tim Penysun Kajian Dewan Mahasiswa Justicia Fakultas Hukum UGM. "Pembahasan Formil.” Sebuah Kajian Mengupas Omnbus Law Bikin Ga(k)Law, 2020. Accessed March 21, 2020.Mengupas-Omnibus-Law-Bikin-GakLaw-8.pdf.

\section{Kamus:}

Garner, Bryan A. "Black's Law Dictionary." United States of America: Thomson Reuters, 2009. epdf.pub_blacks-lawldictionary.pdf.

Kemendikbud."KBBI Daring."KBBI. Jakarta: Badan Pengembangan dan Pembinaan Bahasa, 2016. Accessed April 24, 2020.kbbi.kemendikbud.go.id.

\section{Internet:}

Iskan, Dahlan. “Terminal Omni.”DI's Way, Desember 2019.Accessed June 13, 2020. https://www.disway.id/r/767/terminal-omni.

Novrian, Aditya. "Pakar Hukum UNAIR Sebut Omnibus Law Produk Hukum Yang Lebih Kompleks." UNAIR NEWS. Surabaya, February 11, 2020. Accessed April 5, 2020. http://news.unair.ac.id/2020/02/11/pakar-hukum-unair-sebut-omnibuslaw-produk-hukum-yang-lebih-kompleks/.

Usfunan, Jimmy Z. "Menata Undang-Undang Dengan Omnibus Law.” Hukum Online, Desember 
Volume 16, Nomor 1, Januari - Juni 2021

https://m.hukumonline.com/berita/baca/lt5a28e1bb91cc6/menata-undangundang-dengan-omnibus-law-oleh-jimmy-z-usfunan/.

\section{Peraturan}

PeraturanPemerintah Nomor 24 Tahun 2018 tentang Pelayanan Perizinan Berusaha Terintegrasi Secara Elektronik

Undang-Undang No. 23 Tahun 2014 Tentang Pemerintahan Daerah, n.d.

Rancangan Undang-Undang Cipta Kerja 